\title{
Reformasi Pendidikan Islam Berbasis Pesantren Modern
}

\author{
Sirajun Nasihin \\ STIT Palapa Nusantara Lombok NTB \\ Email : nasihin21272@gmail.com
}

\begin{abstract}
This paper aims to describe the concepts of Islamic education reform based on modern pesantren both from the perspective of experts and referring to the prevailing laws and regulations. In it the author presents; understanding, pattern, and urgency of Islamic education reform based on modern pesantren with the support of data collected using literature review methods either in the form of books or papers and journals downloaded through the internet. From several views that have been collected, the authors conducted a qualitative data analysis and drew the conclusion that the reform of Islamic education based on modern pesantren in the context of this era is absolutely necessary because this education system that can elaborate between rational intelligence, emotional and spiritual integrally so that it can bear output educational, moral, creative, and always able to put themselves in all situations of the nation without having to change its identity as a muslim Indonesia who berpencasila who can realize national goals as embodied in the opening of the 1945 Constitution.
\end{abstract}

Keywords: Reformation, Islamic Education, and Modern Pesantren

\begin{abstract}
Abstrak: Makalah ini bertujuan untuk mendiskripsikan konsep-konsep tentang reformasi pendidikan Islam berbasis pesantren modern baik dari perspektif para ahli maupun mengacu pada peraturan perundangundangan yang berlaku. Di dalamnya penulis menyajikan; pengertian, pola, dan urgensi reformasi pendidikan Islam berbasis pesantren modern dengan dukungan data yang dikumpulkan menggunakan metode kajian pustaka baik berupa buku maupun makalah dan jurnal yang diunduh melalui internet. Dari beberapa pandangan yang telah dihimpun, penulis melakukan analisis data secara kualitatif dan menarik kesimpulan bahwa reformasi pendidikan Islam berbasis pesantren modern dalam konteks zaman ini mutlak diperlukan karena system pendidikan seperti inilah yang dapat mengelaborasi antara kecerdasan rasional, emosional dan spiritual secara integral sehingga dapat melahirkan output pendidikan yang berilmu, bermoral, kreatif dan selalu mampu menempatkan diri dalam semua situasi
\end{abstract}


bangsa tanpa harus merubah jatidirinya sebagai muslim Indonesia yang berpancasila yang dapat mewujudkan tujuan nasional sebagaimana termaktub dalam pembukaan Undang-Undang Dasar 1945.

Kata kunci: Reformasi, Pendidikan Islam, dan Pesantren Modern

\section{Pendahuluan}

Pendidikan Islam dirancang untuk menyiapkan ilmuwan muslim (ulama') yang memiliki wawasan keagamaan yang luas sehingga dapat meneruskan siar Islam sampai di akhir zaman. Di samping itu, ajaran Rasulullah saw yang senantiasa selalu dapat diterima oleh generasi tiap zaman, membuka peluang bagi pendidikan Islam untuk terus secara kreatif menggali ajaran Islam dalam al-Qur'an maupun hadits Rasulullah saw. Oleh karenanya, dalam penyelenggaraannya dibutuhkan kurikulum yang mengakomodir kepentingan masyarakat global tanpa harus mengubur jatidiri kaum muslimin, karena Islam adalah agama yang dipersiapkan oleh Allah swt di bagian akhir kehidupan dunia ini.

Lembaga pertama yang menyelenggarakan pendidikan Islam adalah pondok pesantren yang lahir jauh sebelum kemerdekaan Republik ini, bahkan pondok pesantren memiliki andil yang besar dalam mewujudkan kemerdekaan sebagaimana sejarah membuktikan bahwa pesantren-pesantren yang telah ada sebelum kemerdekaan itu menjadi pusat-pusat pelatihan militer bagi para pemuda dan santri. Ini menunjukkan bahwa pesantren tidak hanya membekali para santri dengan pendidikan agama Islam yang ansich untuk bekal melaksanakan ibadah, akan tetapi juga untuk menjawab tantangan zamannya.

Perkembangan zaman pasca kemerdekaan seiring bergulirnya pergantian rezim dari satu masa ke masa berikutnya, telah membuat pendidikan secara umum menjadi bagian dari kepentingan politik praktis yang menjadi alat perjuangan sekelompok orang tertentu dan pada akhirnya pendidikan Islam seakan dipinggirkan ke sudut ruang dan waktu yang buram. Kebijakan pemerintah terus mengalami koreksi oleh para pemerhati dan pemikir pendidikan Islam hingga lahirlah Undang-Undang Nomor 20 tahun 2003 tentang Sistem Pendidikan Nasional. Lahirnya UndangUndang ini membawa angin segar bagi pendidikan Islam karena keberadaan 
madrasah sebagai lembaga pendidikan Islam di bawah kementerian agama telah disejajarkan dengan sekolah sebagai lembaga pendidikan di bawah kementerian pendidikan. Kesejajaran ini perlu terus dikawal agar tidak hanya berlaku pada hukum formal tetapi keberpihakan itu benar-benar terwujud dalam bentuk penganggaran yang sama di antara keduanya agar tujuan nasional untuk mencerdaskan kehidupan bangsa ${ }^{1}$ benar-benar menjadi tanggung jawab bersama.

Memasuki abad ke 20 bahkan sejak akhir abad ke-19 globalisasi mulai merambah pelosok dunia Islam melalui jalur religio-intelektual di Timur Tengah, kemudian berubah menjadi religio-politik yang dewasa ini dipenuhi nuansa dunia Barat ${ }^{2}$ yang lebih bersifat sosio-ekonomic bahkan sosio-cultural telah menjadi tantangan yang nyata bagi pendidikan Islam dalam menyikapi perubahan budaya yang terjadi sebagai akibat daripada kontak budaya antar bangsa yang menyentuh sendi-sendi kehidupan material maupun spiritual ${ }^{3}$ sehingga dibutuhkan persiapan sistem pendidikan Islam yang mapan dan teruji khususnya untuk mempersiapkan Sumber Daya Manusia yang memiliki rasa nasionalisme yang berpadu dengan islamisme yang mendalam.

Harus disadari bahwa perubahan di era yang modern ini tidak dapat dihindari, akan tetapi perubahan harus disikapi secara cerdas agar tidak tergilas roda kemajuan itu. ${ }^{4}$ Cerdas dalam memilih strategi, cerdas dalam menentukan materi, metode, dan memposisikan diri sebagai lembaga yang tetap mempertahankan tradisionalme yang transcendent sekaligus mengambil posisi di depan dalam penguasaan ilmu pengetahuan dan teknologi.

Lulusan pesantren harus mampu menjadi ahli agama yang akan mengayomi masyarakatnya dalam menjaga nilai-nilai transendental sekaligus dapat memiliki penghasilan tetap dengan menjadi pelaku ekonomi di berbagai sektor dan tidak

\footnotetext{
1 Pembukaan Undang-Undang Dasar 1945 linea ke-empat

2 Azyumardi Azra, Pendidikan Islam : Tradisi dan Modernisasi Menuju Millenium Baru, Jakarta, Logos Wacana Ilmu, 1999, 43-44.

${ }^{3}$ H. Muhtarom, H.M, Reproduksi Ulama di Era globalisasi, Pustaka Pelajar, Yogyakarta, 2005, 44.

${ }^{4}$ Machali, et.al, Pendidikan Islam dan Tantangan Globalisasi; Buab Pikiran Seputar; Filsafat, Politik, Ekonomi, Sosial, dan Budaya, Yogyakarta, Ar-Ruzz Media, 2004, 10.
} 
menjadi peminta-minta dengan cara apapun. ${ }^{5}$ Pengelolaan pesantren seperti ini tentunya tidak terlepas dari tuntutan penguasaan ilmu pengetahuan dan teknologi. Sementara itu, dunia kerja dan dunia usaha membutuhkan tenaga yang di samping memiliki kepribadian yang baik (agamais), juga harus memiliki keahlian dan keterampilan yang memadai dalam bidang yang dibutuhkan. Kondisi riil di tengah masyarakat ini tidak dapat dipandang sebelah mata karena mereka itulah yang menjadi pangsa pasar bagi seluruh lulusan lembaga pendidikan.

Oleh karenanya, penguasaan ilmu akan dikelompokkan menjadi ilmu pokok dan ilmu pendukung. Keduanya sangat penting untuk dikuasai secara teoritis dan praktis. Ilmu pokok akan menghantarkan lulusannya menjadi ilmuwan muslim (ulama) dan ilmu penunjang akan memberikan keahlian dan keterampilan dalam menghadapi tantangan ekonomi, politik, budaya, pertahanan, keamanan, dan lain sebagainya.

Namun sangat disayangkan, lulusan lembaga pendidikan agama (madrasah) terkesan tidak memiliki pemahaman yang cukup terhadap ilmu agama jika diamati dari praktek ibadah sehari-hari. Sebagai contoh yang dapat penulis kemukakan dari pengalaman sehari-hari terhadap praktek wudlu' yang merupakan bagian dari ilmu pokok tadi. Lulusan madrasah tidak lebih baik dari lulusan sekolah dalam praktek wudlu' baik mengenai tata cara maupun pemahaman terhadap air yang sah dan tidak sah dipakai berwudlu'.

Melihat pemandangan-pemandangan semacam ini, penulis bercermin dari pengalaman mengajar di madrasah sampai kepada pengalaman mengajar di Perguruan Tinggi Agama Islam. Waktu yang tersedia secara formal (antara 35-45 menit/Jam Tatap Muka) tidak akan cukup untuk membahas teori secara tuntas apalagi untuk berpraktek, apalagi pemanfaatan waktu yang tidak efektif oleh guru-guru yang dipaksa tunduk pada kebijakan yang tidak mengandung kebajikan. Kondisi ini akan menjadi semakin parah manakala tenaga pengajarnya tidak memiliki pemahaman

\footnotetext{
${ }^{5}$ Ini merupakan bagian sikap pengamalan ajaran QS. Al-Baqarah : 273 yang menyatakan bahwa mereka yang berjuang di jalan Allah dan tidak sempat melakukan usaha ekonomi sehingga orang yang tidak tahu menganggapnya sebagai orang kaya karena mereka menjaga diri dari meminta-minta.
} 
dasar yang kuat dalam ilmu-ilmu agama dan wawasan yang luas dalam ilmu-ilmu social lainnya.

Kenyataan ini harus menjadi masukan yang berharga bagi pemangku kebijakan agar setiap lembaga pendidikan Islam ditekankan untuk menyelenggarakan system pendidikan berbasis pesantren agar dapat memberikan pembekalan yang oftimal bagi para siswa sekaligus sebagai santri. Dengan kata lain, jangan ada lembaga pendidikan Islam yang tidak memiliki pondok pesantren mulai dari jenjang pra sekolah sampai dengan perguruan tinggi.

\section{Rumusan Masalah}

Untuk lebih memudahkan pembahasan dan tetap mengarahkannya pada koridor yang jelas, maka beberapa fenomena kelembagaan yang disajikan pada latar belakang di atas, dipandang penting untuk dihimpun dalam beberapa rumusan masalah sebagai berikut :

1. Aspek apa saja yang paling penting dibenahi untuk mewujudkan reformasi pendidikan Islam?

2. Bagaimana pola reformasi pendidikan Islam berbasis pesantren modern?

3. Mengapa reformasi pendidikan Islam harus berbasis pesantren modern?

\section{Tujuan Pembahasan}

Makalah ini merupakan hasil pemikiran dan kajian pustaka atas berbagai fenomena kehidupan pesantren yang tampak di era modern ini. Adapun pembahasan makalah ini bertujuan sebagai berikut :

1. Untuk menemukan aspek apa yang paling menonjol untuk direformasi dalam penyelenggaraan pendidikan Islam.

2. Untuk mendiskripsikan pola reformasi pendidikan Islam berbasis pesantren modern.

3. Untuk mendiskripsikan alasan mengenai pentingnya reformasi pendidikan Islam berbasis pesantren modern. 


\section{Sekilas Tentang Reformasi}

Reformasi adalah bahasa serapan yang berasal dari bahasa Inggris. Asal katanya adalah re-form yang berarti perubahan, perbaikan. Dari akar kata ini kemudian lahirlah reformation yang kemudian populer disebut reformasi. Reformasi berarti usaha merubah atau keadaan merubah bahan perubahan kecil belaka dan bukan bersifat merubah keseluruhannya. ${ }^{6}$ Dengan demikian berarti reformasi itu merupakan upaya perubahan sebagian dari sistem yang ada dalam suatu tatanan kehidupan yang sudah ada.

Istilah ini lahir dan populer di Indonesia sejak lengsernya penguasa rezim orde baru pada tahun 1998 yang secara terus menerus menggema sampai ke tingkat masyarakat akar rumput sehingga seakan-akan telah menjadi momok yang sangat menakutkan. Padahal sesungguhnya ia bukanlah perubahan yang bersifat merombak total hingga tidak menyisakan bentuk sama sekali.

Tujuan reformasi sesungguhnya adalah untuk melakukan perbaikan terhadap sistem menejeman yang telah disalah arahkan oleh suatu sistem kekuasaan. Lebih tepatnya disebut sebagai sebuah paradigma baru dalam menghadapi tantangan baru, yang oleh Kuhn dikatakan apabila dihadapi dengan menggunakan paradigma lama, maka segalanya akan gagal ${ }^{7}$ lebih-lebih dalam sektor pendidikan yang menjadi tonggak kehidupan suatu bangsa dan negara, termasuk di dalamnya adalah reformasi di bidang pendidikan Islam.

Reformasi pendidikan akan berjalan secara alamiah karena tantangan yang muncul tiap etape zaman akan terus mengalami perubahan yang menuntut perubahan desain pendidikan itu sendiri. Pendidikan Islam yang berkembang pesat sampai saat ini, juga akan mengalami persoalan yang sama dengan pendidikan umum, oleh karenanya harus didesain sesuai dengan tantangan zaman agar terus dapat menyesuaikan diri dengan perubahan yang berlangsung. ${ }^{8}$ Desain pendidikan

${ }^{6}$ Yose Rizal SM dan David Sahrani, Kamus Populer Kontemporer, (Jakarta : Restu Agung, cetakan ke-5, 2004), 301-302.

${ }^{7}$ Lihat Tilaar (1998 : 245) dalam Hujair AH. Sanaky, Reformasi Pendidikan Suatu Keharusan Untuk Memasuki Millenium III (Suatu Renungan Untuk Pendidikan Islam) ,https://tikaliyah.files.wordpress.com/2010/03/ reformasi-pendidikan.pdf, hal. 1. diunduh tanggal 1 Mei 2017 pukul $13: 24$

${ }^{8}$ Ibid. 
Islam meliputi substansi problem administrasi pendidikan yang terdiri dari ; kurikulum, ketenagaan, kesiswaan, sarana prasarana, keuangan, perkantoran, dan humas.

Pendidikan Islam yang umumnya dikelola dengan pola pondok pesantren tradisional akan melakukan perbaikan dari sisi-sisi substantif di atas tanpa mengabaikan sifatnya yang tradisional karena di sisi inilah nilai sejarahnya sangat melekat. Nilai tradisionalitas ini dapat dipola menjadi modern-tradisional. Modern berarti menganut sistem menejemen yang memanfaatkan kemajuan teknologi informasi dan komunikasi sedangkan tradisional berarti tetap mempertahankan norma-norma dan budaya klasik ketimuran. Reformasi akan berlangsung pada beberapa subtstansi antara lain; model pembelajaran interaktif multimedia, pembelajaran berbasis internet, desentralisasi pendidikan, kemudahan saling tukar informasi, berorientasi kepada siswa dengan pola inquiry, ${ }^{9}$ dan bentuk lainnya yang dipandang relevan dengan tuntutan kemajuan serta menempatkan siswa benar-benar sebagai subyek pendidikan bukan hanya sebagai obyek.

\section{Reformasi Pendidikan Islam}

Sebuah analogi yang sangat relevan dengan kenyataan pendidikan Islam saat ini adalah laksana mencampur bensin dengan air. Bensin yang merupakan bahan bakar dan air yang merupakan kebutuhan pokok makhluk hidup. Kedua sumber daya ini sangat penting bagi kehidupan manusia selama kondisinya masih bisa dimanfaatkan. Lain halnya dengan ketika keduanya dicampur aduk. Sebagai bensin, ia tidak akan pernah dapat dipergunakan sebagai bahan bakar kendaraan bermotor manakala telah bercampur air, dan sebaliknya air tidak akan pernah dapat diminum manakala telah bercampur bensin.

Pendidikan Islam modern saat ini diselenggarakan dengan muatan kurikulum yang cukup padat baik dengan ilmu-ilmu agama Islam maupun ilmu sosial, ilmu alam, ilmu hukum, ilmu seni, kesehatan dan lain sebagainya. Campuran ini cukup baik dan bagus, akan tetapi akan menghasilkan sesuatu yang

9 Baca Reformasi Pendidikan di Era Disinformasi, (Kendari : Prodi Pendidikan Matematika Universitas Halu Uleo, 2014, 5-7. dalam https://listy2812.files.wordpress.com/2014/01/reformasipendidikan-di-era-disinformasi.pdf diunduh tanggal 1 Mei 2017 pukul 13: 15 
tidak dapat dimanfaatkan secara oftimal oleh konsumen. Produk pendidikan Islam kadang tidak bisa menjadi ahli agama atau ahli social atau ahli hukum atau ahli ekonomi dan lain sebagainya disebabkan pembelajaran pada masing-masing bidang itu tidak focus dan tidak maksimal.

System seperti ini dalam hemat penulis tidak harus diubah akan tetapi memerlukan kebijakan baru agar semua lembaga pendidikan Islam dapat diselenggarakan berbasis pondok pesantren. Pondok pesantren yang terus dapat mengejar ketinggalan adalah pesantren yang dikelola secara modern baik kurikulum, metode, sarana, dan menejemennya sehingga tidak harus dihantui oleh fobia terhadap isu radikalisme.

Sikap radikalisme akan tumbuh pada otak dan hati yang belum matang pada saat ia bertemu dengan pengaruh baru. Ketika seseorang telah dengan matang memahami ajaran agamanya, maka tidak akan mudah untuk dirasuki oleh doktrin baru. Sebaliknya apabila pemahaman agamanya masih setengah matang, maka ia akan menganggap faham baru itu merupakan faham asli yang dating dari zaman generasi Islam pertama. Padahal ajaran Islam itu akan membuat penganutnya menjadi manusia yang berwawasan luas dan bersikap fleksibel dalam menerima perbedaan. Karena radikal bukanlah sikap yang diajarkan oleh baginda Rasulullah saw selama masa dakwahnya, ketika mengutus Abu Musa dan Mu'adz ke Yaman. Beliau berpesan :.."Mudabkan jangan mempersulit !, gembirakan dan jangan menakutnakuti! dan hendaklah kalian saling terbuka dan bersuka hati ! $!^{10}$

Untuk menghindarkan ilmu setengah matang inilah, maka reformasi pendidikan Islam dibutuhkan mulai dari pemadatan dan penajaman pemahaman dalam ilmu-ilmu agama terutama kajian kitab klasik dengan bahasa Arab yang didukung penguasaan ilmu nahwu dan shoraf atau dengan kata lain dibuthkan reformasi kurikulum dan kelembagaan.

${ }^{10}$ H.R. Bukhari Muslim dari Abi Burdah. Ahmad al-Hasyimi Beik, Mukhtar al-Ahaadits, Daar Ihya alkutub al-'Arabiyyah, Indonesia, 1948, hal.187, menyajikan hadits dalam lafaz yang lain diriwayatkan oleh Bukhori dengan menggunakan dhomir jama' yang mengisyaratkan perintah yang umum bukan hanya kepada Abu Musa dan Mu'adz. 


\section{Urgensi Pesantren Modern dalam Reformasi Pendidikan Islam}

\section{Pengertian Pondok Pesantren}

Nurcholis Madjid dalam Andy Andriansyah ${ }^{11}$ mengatakan bahwa kata santri yang menjadi akar kata pesantren - berasal dari dua kata yaitu : sashtri (Sangskerta) yang berarti melek huruf dan cantrik (Jawa) yang berarti seseorang yang selalu mengikuti seorang guru ke manapun guru itu menetap. Pondok Pesantren yang terdiri dari dua kata memberikan pemahaman bahwa pondok adalah tempat menetap sementara, pesantren adalah tempat proses pembelajaran (interaksi guru-murid) secara berkelanjutan.

Tidak perlu terlalu banyak teori yang dihadirkan untuk memahami istilah ini karena terlalu banyak berdebat dalam memberikan pemahaman terhadap term ini akan membuat kita kehabisan waktu untuk berfikir realistis. Yang jelas bahwa pondok pesantren berarti pendidikan harus berlangsung bagi siswa yang disantrikan (diakomodir dalam pondok) agar dapat mengikuti pembelajaran secara oftimal sehingga pihak-pihak tertentu tidak terkesan asal-asalan dalam mendirikan lembaga pendidikan Islam. Kita butuh persiapan yang matang dan tidak perlu berbangga dengan tumbuhkembangnya lembaga pendidikan Islam yang sangat pesat mengalahkan jumlah jamur di musim hujan.

\section{Pesantren Modern sebagai Basis Reformasi Pendidikan Islam}

Pondok Pesantren sampai saat ini memiliki berbagai type baik tradisional, semi modern, dan modern. Kriteria sebuah lembaga disebut sebagai pondok pesantren adalah padanya terdapat 5 ciri yakni ; asrama, kyai, masjid, madrasah, dan kitab kuning. Kriteria ini mengacu pada tipe pesantren tradisional yang memang harus terus berkembang meskipun pada kenyataannya banyak juga pesantren yang tidak memiliki ciri itu secara komplit. Pondok pesantren modern tidak hanya dilihat dari kelima ciri itu, tetapi harus dilengkapi dengan rumah sakit (klinik), perusahaan, jaringan internet, dan tempat-tempat pelatihan keterampilan lainnya.

\footnotetext{
11 lihat Andy Andriansyah,Menejemen Pesantren, http://andyandriansyah.blogspot.co.id/2008/11/manajemen-pesantren.html diunduh tanggal 1 mei 2017 pukul 14:45
} 
Reformasi pendidikan Islam nampaknya perlu diarahkan kepada terbentuknya secara kelembagaan menjadi pondok pesantren modern dengan beberapa alasan sebagai berikut :

a. Pondok Pesantren Konsep Pendidikan Terbaik

Keberadaan pesantren sepanjang sejarahnya senantiasa eksis bahkan mengalami perkembangan yang sangat signifikan. Ini dapat menjadi indikator bahwa lembaga ini sangat dicintai oleh masyarakat di setiap zamannya. Ada beberapa alasan yang mendasari pernyataan ini sebagaimana Afif Hasan menuliskan;

Pernyataan Afif Hasan di atas telah diperkuat dengan pengakuan beberapa ilmuan antara lain; Horiko Horikoshi yang menyebut pesantren sebagai social change, Clifford Geertz menyebutnya sebagai cultural broker, Komaruddin Hidayat menyebutnya sebagai mediator kehidupan modern dan tradisional, Thoha Hamim menyebutnya sebagai regulator keadaan masyarakat yang tidak menentu, Munandir Soelaiman menyebutnya sebagai stabilisator sama dengan apa yang dikemukakan oleh Atho’ Mudzhar, bahkan menurutnya kiprah kiyai di sini diterapkan dengan prinsip stability and change. ${ }^{12}$

b. Pesantren memiliki sifat dinamis

Sifat tradisional yang menjadi ciri khas pesantren, bukanlah membuatnya harus tertutup terhadap perubahan. Pesantren yang bertahan sepanjang sejarah ini adalah pesantren yang senantiasa terbuka menerima nilai baru (modernisasi) sedangkan pesantren yang tidak terbuka akan memiliki kendala dalam mencapai kemajuan. Ia akan menjadi lembaga yang jumud dan tidak akan diminati banyak orang.

Masalah yang sangat mungkin terjadi pada pondok pesantren adalah masalah menejemen, di mana sifat tradisional tadi telah mengekangnya sehingga tidak menerapkan menejemen secara profesional dengan skil-skil yang 
diperlukan seperti buman skill, conceptional skill, dan technical skill. ${ }^{13} \mathrm{Hal}$ inilah yang menyebabkan beberapa pesantren menjadi merosot.

c. Pesantren Dapat Mengikuti Arus Modernisasi

Pondok pesantren dapat menyelenggarakan pendidikan sekaligus dengan dua pola yakni pola tradisional dan pola modern, jalur sekolah yaitu madrasah dan jalur luar sekolah yaitu diniyyah Islamiyah, jenis pendidikan umum dan pendidikan agama.

Perubahan zaman telah menempatkan pesantren dalam mengambil sikap, terbagi menjadi empat kelompok yaitu ; pertama, kelompok yang kurang tanggap terhadap kondisi dirinya. Kelompok ini nampaknya mendominasi pesantren yang ada. Kedua, bersikap apologis yaitu menganggap bahwa apapun yang diterapkan di pesantren adalah positif dan harus dipertahankan. Ketiga, merasa rendah diri menghadapi perubahan sehingga ia kehilangan kesempatan, dan Keempat mengoreksi diri dan terbuka menerima perubahan. Kelompok terakhir ini jumlahnya paling sedikit ${ }^{14}$ namun inilah yang akan eksis sepanjang zaman.

Tradisi negatif yang menghambat pesantren untuk maju adalah tradisi pengkultusan terhadap pimpinan yang disebut kiyai (jawa), tuan guru (Lombok) serta keturunannya yang dilakukan secara berlebihan. Akan tetapi, dengan semakin banyaknya pondok pesantren yang menyelenggarakan pendidikan tinggi, agaknya sikap ini mulai terkikis sedikit demi sedikit sehingga mulai menerima angin perubahan.

d. Pesantren Dapat Menguasai Sains dan Teknologi

Sains bukanlah hanya milik dunia Barat meskipun antara Timur dan Barat memiliki perbedaan epistemologi. Dunia Barat hanya menggunakan panca indera dan akal, sedangkan dunia Islam disamping menggunakan keduanya juga memiliki signal wahyu yang dapat ditelusuri. Epistemologi Timur berdiri di atas dua pilar sekaligus yaitu teosentris dan antroposentris,

13 Andy Andriansyah, op.cit.

${ }^{14}$ H. Amin Haedari, et.al, Panorama Pesantren Dalam Cakrawala Modern, Diva Pustaka, Jakarta, 2004, 8687. 
sedangkan epistemologi Barat hanya bersel tunggal yakni positivisme yang menuntut sistematisasi dan alam fikir ilmiah. ${ }^{15}$

Pesantren mengembangkan kematangan spiritual untuk melangkah di jalan menuju Tuhan. Oleh karenanya, orang-orang pesantrenlah yang seharusnya terlebih dahulu menerima kehadiran sains sebagai wujud kebenaran paradigma positivisme. Karena al-Qur'an memang menantang umat manusia untuk mencari kebenaran (al-Haq) itu melalui dua jalur yakni Bumi (alam) dan jiwa manusia (al-anfus). ${ }^{16}$

Dunia sains mutakhir memperlihatkan kebenaran ajaran agama yang berkembang di dunia Timur yang hampir keseluruhannya memiliki dimensi ilmiah yang spektakuler. ${ }^{17}$ Dan ternyata, al-Qur'an telah menempatkan wilayahwilayah penelitian bagi pengembangan ilmu pengetahuan dan teknologi yang hanya dapat dijangkau oleh manusia yang telah dilengkapi dengan potensi kekuatan berupa otak dan segala sistemnya. ${ }^{18}$ Pemahaman yang terpadu antara sains dan al-Qur'an hanya dapat ditempuh melalui pendalaman terhadap isyarat al-Qur'an yang dapat diperoleh melalui pendidikan di pondok pesantren.

\section{Strategi Pesantren Menuju Modernisasi}

Agenda terbesar yang harus dilakukan pesantren adalah; pertama, membongkar nalar kritis dengan menciptakan suasana itu dalam dirinya. Kritik terhadap diri sendiri dan kritik terhadap nilai luar yang diadopsi. Kedua, profesionalisasi lembaga yang mengandung arti tidak hanya bergantung pada trah darah sang kiyai tanpa melihat kemampuan emosional-intelektualnya. Ketiga, filterisasi terhadap agenda modernisasi agar dapat memilah dan memilih mana yang baik dan

\footnotetext{
15 Mihrab, edisi II, tahun III, November 2005, 5.

16 QS.Adzaariyat ; 21 menyebutkan "dan di bumi terdapat sinyal-sinyal (kekuasaan Allab) bagi orang-orang yang berkeyakinan. Dan dalam dirimu (juga), maka apakah kamu tidak dapat melihatnya?"

17 Taufiq Pasiak, Revolusi IQ/EQ/SQ ; Menyingkap Rahasisia Kecerdasan Berdasarkan Al-Qur'an Dan Neurosains Mutakbir, Mizan, Bandung, 2008, 255-256.

${ }_{18}$ QS. Al-Rahman: 33.
} 
mana yang buruk $^{19}$ sebagaimana berfikirnya muslim progresif; engage with tradition, multiple critique, dan terbuka terhadap sumber pengetahuan skunder. ${ }^{20}$

Pesantren modern tidak hanya berorientasi pada penyiapan output yang memiliki bekal ilmu-ilmu keagamaan, akan tetapi juga menyiapkan angkatan kerja yang berkualitas lahir dan bathin dari segi pendidikan dan moral yang luhur. Karena tidak dapat dipungkiri bahwa angkatan kerja yang berdedikasi tinggi belum tentu memiliki moral kerja yang tinggi pula, lebih-lebih tenaga kerja di negara kita saat ini sebagian besar tidak bependidikan. Budiono mengungkap bahwa 53\% angkatan kerja tidak berpendidikan, 34\% berpendidikan dasar, 11\% berpendidikan menengah, dan hanya $2 \%$ berpendidikan tinggi. ${ }^{21}$ Jika kondisi ini ditambah lagi dengan minimnya nilai moralitas agama, maka korupsi, kolusi dan nepotisme tidak terjadi hanya di kalangan pejabat tinggi akan tetapi akan mulai dari pejabat kelas rendah bahkan di tingkat karyawan rendahan.

\section{Pesantren Menghadapi Arus Globalisasi}

Pemikiran liberal adalah bagian dari ciri kehidupan global. Liberalisme bertentangan dengan idiologi negara, akan tetapi kenyataan tidak dapat dipungkiri. Pesantren saat ini tengah menghadapi benturan peradaban antara nilai tradisional yang dianggap transenden dengan nilai modernitas. Mau tidak mau proses akulturasi harus dilalui tanpa harus "menelanjangi” karekteristiknya.

Kekhawatiran yang berlebihan dalam menyikapi arus global justeru sangat tidak beralasan. Di era global jumlah pesantren tidak menjadi berkurang dan kehilangan peminat, tetapi justeru semakin mekar dan semerbak. Di samping itu, pesantren tidak hanya menghasilkan da'i dan muballigh, tetapi juga pejabat negara, politisi, pengusaha, artis, dan konglomerat. Jika pesantren tetap takut dan mempertahankan tradisionalitasnya, maka sangat tidak mungkin menghasilkan orangorang sukses seperti ini. Sikap terbuka inilah yang telah membuat pesantren mampu bertahan dan akan terus bertahan sepanjang zaman.

\footnotetext{
${ }^{19}$ Ibid, 91-92.

${ }^{20}$ Omid Safi, Progressive Muslim on Justice, Gender, and Pluralism, England, One World Publications, 2003, 5-15.

${ }^{21}$ Hujair AH. Sanaky, op. Cit.
} 


\section{Kesimpulan}

Berdasarkan uraian di muka, maka penulis dapat menarik kesimpulan bahwa reformasi pendidikan Islam sangat penting dan harus berbasis pesantren dengan beberapa pernyataan sebagai berikut :

1. Reformasi dilakukan terhadap aspek kelembagaan dan kurikulum dimana kebijakan pemerintah sangat berperan dalam menegaskan pentingnya pondok pesantren bagi tiap lembaga pendidikan Islam serta di dalam kurikulumnya mata pelajaran agama Islam diberikan tambahan waktu sekurangnya 50\% dari waktu yang ada sebagai tambahan pembelajaran di pesantrennya.

2. Agar dapat menjawab tantangan zaman dan tidak tertinggal oleh kemajuan orang lain, maka reformasi pendidikan Islam diarahkan agar berbasis pesantren modern dengan pola-pola yang telah dipaparkan.

3. Berbasis Pesantren modern mengandung pesan agar pendidikan Islam tetap mempertahankan cirri khasnya yang transcendental truts tetapi dapat menerima ilmu skundair dan nilai-nilai perubahan yang disesuaikan dengan kebutuhan zamannya agar tidak terjebak pada sikap radikalisme sempit.

\section{Daftar Pustaka}

Abdul Baqi, Muhammad Fu'ad, Al-Mu'jam al-Mufahras Li Alfari Al-Qur'an Al-Karim, CV. Diponegoro, Bandung, 1945

Andriansyah, Andy,

Manajeman

Pesantren,

http:/ / andyandriansyah.blogspot.co.id/2008/11/manajemen-pesantren.html diunduh tanggal 1 mei 2017 pukul 14:45

Azra, Azyumardi, Pendidikan Islam; Tradisi dan Modernisasi Menuju Milenium Baru, Jakarta, Logos Wacana Ilmu, 1999.

Beik, Ahmad al-Hasyimi, Mukhtâru al-Ahâditsi al-Nabawiyyah wa al-Hikamu alMuhammadiyyah, cetakan ke-6, Indonesia, Dâr Ihya’i al-Kutubi al-'Arabiyyah, 1948. 
Departemen Agama RI, Panduan Praktis Pelayanan Pondok Pesantren Pada Masyarakat Bidang Ta'lim, Dirjen Bagais, Direktorat PK Pontren, Proyek Peningkatan Pendidikan Luar Sekolah Pada Pondok Pesantren, Jakarta, 2004.

Haedari, H. Amin, dkk, Panorama Pesantren Dalam Cakrawala Modern, Jakarta, Diva Pustaka, 2004.

Hasan, Afif, Ilmu Pendidikan Islam : Refleksi Pencarian Spektrum Pendidikan Islam, Malang, UM.Press IKIP Malang, 2011.

Machali, Imam dan Musthofa, Pendidikan Islam dan Tantangan Globalisasi; Buah Pikiran Seputar; Filsafat, Politik, Ekonomi, Sosial, dan Budaya, Yogyakarta: Ar-Ruzz Media, 2004.

Mihrab Jurnal, Pesantren Dan Sains, edisi II, tahun III, November 2005, Jakarta, Dir PK Pontren dan CV. Kawula Muda, 2005.

Muhtarom, H.M, H, Reproduksi Ulama di Era globalisasi, Pustaka Pelajar, Yogyakarta, 2005.

Suwarno, Wiji, Dasar-Dasar Ilmu Pendidikan, Ar-Ruz Media, Yogyakarta, 2006.

Paisol, Gus Dur dan Pendidikan Islam : Upaya Mengembalikan Esensi Pendidikan di Era Global, Jakarta, Ar-Ruz Media, 2011.

Pasiak, H. Taufiq, Revolusi IQ/EQ/SQ : Menyingkap Rabasia Kecerdasan Berdasarkan AlQur'an Dan Neurosains Mutakhir, Bandung, Mizan, 2008.

http://www.cnnindonesia.com/nasional/20160531155543-20-

134779/kemendikbud-ingin-perbanyak-sekolah-pengguna-kurikulum-2013/, diunduh tanggal 3 Januari 2017, pukul 00:25.

Sanaky, Hujair AH., Reformasi Pendidikan Suatu Keharusan Untuk. Memasuki Millenium III (Suatu Renungan Untuk Pendidikan Islam) https://tikaliyah.files.wordpress.com/2010/03/reformasi-pendidikan.pdf diunduh tanggal 1 Mei 2017 pukul $13: 24$ 
Sapulidi Riset Center (SRC), Statistik Pendidikan, Sapulidi tahun 2016, http://bangimam-berbagi.blogspot.co.id/2016/04/ini-data-guru-honorer2016.html, diunduh tanggal 2 Januari 2007, pukul 23:57.

Suharto,Toto, Konsep Dasar Pendidikan Berbasis Masyarakat, Jurnal Cakrawala Pendidikan, November 2005, th. XXIV, No.3, (Palembang : Fakultas Tarbiyah IAIN Raden Patah) http://seputarpendidikan003.blogspot.co.id/2013/06/pendidikan-berbasismasyarakat.html, diunduh tanggal 2 Januari 2017, jam 23:45.

Tohirin, at.al, Sistem Manajemen Pendidikan Dan Pengelolaan Pondok Pesantren, Fakkultas Ilmu Tarbiyah Dan Keguruan (FITK) Universitas Sains Al-Qur'an (UNSIQ) Jawa Tengah, http://sholihfikr.blogspot.co.id/2014/04/sistem-manajemen-pendidikan-dan.html diunduh tanggal 1 Mei 2017 pukul 14:40

https://listy2812.files.wordpress.com/2014/01/reformasi-pendidikan-di-eradisinformasi.pdf diunduh tanggal 1 Mei 2017 pukul $13: 15$

https://insaniaku.files.wordpress.com/2009/03/3-reformasi-sistem-pendidikanislam-di-indonesia-siswadi.pdf diunduh tanggal 1 Mei 2017 pukul $13: 20$ https://goeroendeso.files.wordpress.com/2009/01/reformasi-sistem-pendidikan.pdf diunduh tanggal 1 Mei 2017 pukul $13: 22$

https://ppispanyol.files.wordpress.com/2010/06/20-tahun-reformasi-pendidikantinggi-spanyol.pdf dinduh tanggal 1 Mei 2017 pukul $13: 26$

http:// file.upi.edu/Direktori/FIP/JUR._ADMINISTRASI_PENDIDIKAN/19530 6121981031-UDIN_SYAEFUDIN_SA'UD/Paradigma_Baru_PendidikanITB.pdf diunduh tanggal 1 Mei 2017 pukul $13: 33$

http://eprints.uny.ac.id/3789/1/A01-toto.pdf diunduh tanggal 1 Mei 2017 pukul $13: 38$

http://lib.unnes.ac.id/16894/1/1103504040.pdf diunduh tanggal 1 Mei 2017 pukul $13: 40$

https://aristhu03.files.wordpress.com/2006/10/manajemenpendidikan.pdf diunduh tanggal 1 Mei 2017 pukul 14:10 